\title{
GENETIC DIVERSITY STUDY OF MODERN RUSSIAN APPLE (Malus $\times$ domestica Borkh.) CULTIVARS BY THE SSR LOCI ANALYSIS
}

\section{I.I. SUPRUN ${ }^{1}$, Ya.V. USHAKOVA 1 , S.V. TOKMAKOV ${ }^{1}$, Ch.E. DUREL ${ }^{2}$, C. DENANCÉ2 ${ }^{2}$ E.V. UL'YANOVSKAYA ${ }^{1}$}

\begin{abstract}
${ }^{1}$ North Caucasian Regional Research Institute of Horticulture and Viticulture, Federal Agency of Scientific Organizations, 39, ul. 40-letiya Pobedy, Krasnodar, 350901 Russia, e-mail kubansad@kubannet.ru, supruni@mail.ru; 2 National Institute for Agricultural Research (INRA), Centre Angers-Nantes, 42 rue Georges Morel - BP 60057, 49071 Beaucouzé cedex - France

Supported by Russian Foundation for Basic Research (project № 13-04-02089_a). The work was partly funded by the EU seventh Framework Programme through the FruitBreedomics Project («Integrated approach for increasing breeding efficiency in fruit tree crops»; Number 255582).

Received January 27, 2015
\end{abstract}

\section{Abstract}

SSRs are one of the most suitable DNA-markers for assessment of genetic diversity of plant genetic resources. Microsatellites were used for development of saturated genetic maps of apple (Malus $\times$ domestica Borkh.) as well as for wide range of genetic diversity studies. Our study was aimed on the investigation of the genetic relationship within subcollection of modern Russian apple cultivars. Polymorphism of 12 microsatellite loci was estimated for 31 apple cultivars from the SKZNIISiV collection of genetic resources. These cultivars have been bred in North Caucasian Regional Research Institute of Horticulture and Viticulture (SKZNIISiV) and All-Russian Research Institute of Fruit Crop Breeding (VNIISPK). SSR-markers CH01f03b, CH01h01, $\mathrm{CH} 01 \mathrm{~h} 10, \mathrm{CH} 02 \mathrm{c} 06, \mathrm{CH} 02 \mathrm{~d} 08, \mathrm{CH} 04 \mathrm{e} 05, \mathrm{CH} 05 \mathrm{f06}, \mathrm{CH} 01 \mathrm{f02}, \mathrm{CH} 02 \mathrm{c} 11, \mathrm{Hi02c07}, \mathrm{CH} 02 \mathrm{c09}$ and $\mathrm{CH} 03 \mathrm{~d} 07$, which are recommended by Fruitbreedomics, the European consortium, were used in the study. According to the data of SSR-analysis from 5 to 10 alleles per locus were detected, with an average value of 7.75 alleles per locus. A total of 93 alleles were detected for all 12 loci. All apple cultivars showed individual, distinct SSR-profiles. Comparison with the data on the genetic diversity of the world apple tree gene pool suggests that the SSR-loci polymorphism in studied set of the apple cultivars is relatively high. Expected $\left(\mathrm{H}_{\mathrm{e}}\right)$ and observed $\left(\mathrm{H}_{\mathrm{o}}\right)$ heterozygosity varied within the ranges of $0.548-0.897$ and $0.602-0.827$ for $\mathrm{H}_{\mathrm{o}}$ and $\mathrm{H}_{\mathrm{e}}$, respectively. The average values of these indexes are $\mathrm{H}_{\mathrm{o}}=0.786$ and $\mathrm{H}_{\mathrm{e}}=0.755$. PIC value ranged from 0.571 to 0.806 , and 9 loci showed PIC value higher than 0.712. Results of UPGMA-analysis are consistent with the level of genetic heterogeneity of the studied cultivar set. Five clusters were determined. Distribution of cultivars into clusters in most cases is consistent with their genealogy. For example, Svezhest' cultivar, formed a distinct cluster № 1, as well as cultivars Imrus and Zimnee utro which formed cluster № 5 are originated from the cultivars, which are not presented as the parental forms of any studied cultivars. Cultivars of VNIISPK breeding such as Solnishko, Stroevskoe, Yubilei Moskvy, Afrodita and Start, which formed distinct cluster № 3 have one common parental cultivar. The structure of dendrite obtained when performing clustering on the results of SSR-analysis may be due to large number of unique alleles studied in genotypes that in turn is due to the high genetic diversity within the studied set of cultivars. At the same time, the fact of incorporation of cultivars with the same genealogy in the same clusters confirms the high significant genetic similarity within groups of such varieties. Results of the study allows to assess the level of the genetic diversity within the set of modern apple cultivars as well as can be used for confirmation of genealogy of apple cultivars and hybrids in the case of disputes, as well as for identification of varieties.

Keywords: apple tree, SSR-markers, genotyping, polymorphism, genetic diversity.

The use of DNA markers in analysis of plant genetic resources allows us to significantly extend the field of study, from assessment of genetic diversity and issues of variety certification to protection of breeders' copyright and determination of breeding material genetic purity.

DNA markers shall have certain properties and meet a number of requirements, including, in particular, a high level of polymorphism, a codominant nature of inheritance, optimum frequency of occurrence in genome, uniform distribution in chromosomes, easy assessment of marker parameters, high repro- 
ducibility, capability of automated assessment and easy data exchange between laboratories [1]. Microsatellite DNA markers based on Simple Sequence Repeat (SSR) analysis fully comply with these requirements and are currently acknowledged to be one of the most efficient DNA marker systems used in breeding and genetics of cultivated plants, including the apple tree [2-4].

SSR-markers were used for construction of the first most complete genetic maps of the apple tree For example, C. Maliepaard et al. [5] developed one of the first apple tree genome maps with 17 linkage groups with the use of multiallelic markers, including SSR, based on the hybrid population created by crossing of varieties Prima and Fiesta. Later on, identification of new SSR loci in the apple tree genome made it possible to create more comprehensive genetic maps [6-9]. Information about the identified SSR loci and their genome localization provides a valuable scientific base for genetic studies of the apple tree, in particular, for mapping the genes responsible for economic characters, analyzing the genetic pattern of genetic resource collections, certifying the gene pool and investigating genetic diversity within the species Malus $\times$ domestica Borkh.

A wide range of studies aimed at assessing genetic polymorphism in collections of genetic resources (both modern varieties and native gene pool) have been performed by now. Work has been performed to clarify the questions regarding the genealogy of local varieties, formation of autochthonous geneplasm of the apple tree, its genetic interrelation with the global gene pool [10-15], as well as DNA certification of tree stocks [16, 17]. Uniqueness of the aboriginal gene pool has been revealed in a number of cases. The results obtained by A. Gharghani et al. [13] have shown that native Iranian varieties fall in between European apple tree varieties and the species Malus orientalis Uglitz. A. Patocchi et al. [18] have carried out a large-scale study where 88 microsatellite DNA markers were used to assess polymorphism for a total of about 2,000 specimens from European collections of genetic resources (varieties, hybrid populations). These data were used as a basis for recommendations on the most promising SSR markers for analysis of apple tree genomic polymorphism [18].

When genetic diversity of large genetic collections of the apple tree is studied, including wild forms and interspecies hybrids along with varieties, SSR markers also make it possible to objectively assess phylogenetic relationships at intra- and interspecies level [19, 20].

Analysis of SSR loci polymorphism in studies of genetic diversity allows making DNA certificates of genotypes. SSR fingerprints can be efficiently used for identification of specimens of collections, identification of doubles, etc.

Taking into account that the study of apple tree gene pool diversity is highly topical and the use of microsatellite markers in solution of such tasks is very promising, we have carried SSR genotyping of modern varieties for the genetic resource collection of North Caucasian Regional Research Institute of Horticulture and Viticulture (SKZNIISiV) and assessed genetic polymorphism in the modern domestic gene pool of the apple tree.

Technique. The material for the studies was the samples of modern apple tree varieties (SKZNIISiV and All-Russian Research Institute of Fruit Crop Breeding - VNIISPK, Orel, as the originators) stored in SKZNIISiV's collection of genetic resources $(n=31)$.

A total of 12 SSR markers were involved in the work, namely CH01f03b, CH01h01, CH01h10, CH02c06, CH02d08, CH04e05, CH05f06, $\mathrm{CH} 01 \mathrm{f02}, \mathrm{CH} 02 \mathrm{c} 11, \mathrm{Hi02c07}, \mathrm{CH} 02 \mathrm{c09}$ and $\mathrm{CH} 03 \mathrm{~d} 07$. The above listed SSR markers are recommended by European Consortium FruitBreedomics for study of apple tree genetic diversity (a primer sequence is available in a da- 
tabase at http://www.hidras.unimi.it).

DNA was extracted using the CTAB method [21]. PCR was carried out using standard methods with preliminary optimization of parameters. The PCR mix contained 50-70 $\mu \mathrm{g}$ of DNA, $0.05 \mu \mathrm{mM}$ of dNTPs, by $0.3 \mu \mathrm{M}$ of each primer, $0.5 \mu \mathrm{l}$ of $10 \times$ reaction buffer, $2.5 \mathrm{mM}$ of $\mathrm{MgCl}_{2}, 1 \mathrm{U}$ of Taq polymerase; the final volume of $25 \mu \mathrm{l}$. Amplification conditions were as follows: initial denaturation for $5 \mathrm{~min}$ at $95{ }^{\circ} \mathrm{C}$; denaturation for $10 \mathrm{~s}$ at $95{ }^{\circ} \mathrm{C}$, primer annealing for $30 \mathrm{~s}$ at $58^{\circ} \mathrm{C}$, elongation for $30 \mathrm{~s}$ at $72{ }^{\circ} \mathrm{C}$ (30 cycles); final elongation for $3 \mathrm{~min}$ at $72{ }^{\circ} \mathrm{C}$. The reaction was carried out in an Eppendorf Mastercycler Gradient amplifier (Germany), and the fragment analysis of SSR loci was performed using an ABI Prism 3130 automatic genetic analyzer (USA). The results of the fragment analysis were processed in the GeneMapper v. 4.1 software program.

In assessment of microsatellite analysis data, a genetic distance matrix was constructed using similarity coefficients (indices) according to M. Nei и $\mathrm{W}$. Li [22]. The cluster analysis was performed by the Unweighted Pair Group Method with Arithmetic Mean (UPGMA) with the use of FreeTree Application v. 0.9.1.50 (ZDAT v.o.s.). The dendrogram construction was performed using the TreeView (Win32) v. 1.6.6 software program. The actual $\left(\mathrm{H}_{\mathrm{o}}\right)$ and expected $\left(\mathrm{H}_{\mathrm{e}}\right)$ heterozygosity was calculated using GenAlEx v. 6.3 software program. The PIC (Polymorphism Information Content) value was determined using the PICcalculator software program in the online mode (http://w3.georgikon.hu/pic/english/kodom.aspx).

Results. The selected microsatellite markers were tested using electrophoresis in $8 \%$ nondenaturing polyacrylamide gel. After PCR parameter optimization, microsatellite DNA markers were grouped into multiplex kits (4 markers per kit) for simultaneous analysis by several loci. In this case, the sizes of the amplified fragments did not overlap, and each of the markers contained a specific fluorescent tag (FAM, TAMRA, R6G, ROX).

The fragment analysis gave clear reproducible results. As an example, Figure 1 (visualization of results in a working window of the GeneMapper v. 4.1 software program) shows data for variety Krasny Yantar. It can be seen in the electrophoretogram that there were two peaks for the markers indicative of two products, i.e. the corresponding loci are heterozygous. In the discussed case, these are markers $\mathrm{CH} 01 \mathrm{~h} 01, \mathrm{CH} 01 \mathrm{f03b}$, and $\mathrm{CH} 02 \mathrm{c} 06$. One peak for locus $\mathrm{CH} 01 \mathrm{~h} 10$ on the electrophoretogram gave evidence of its homozygosity.

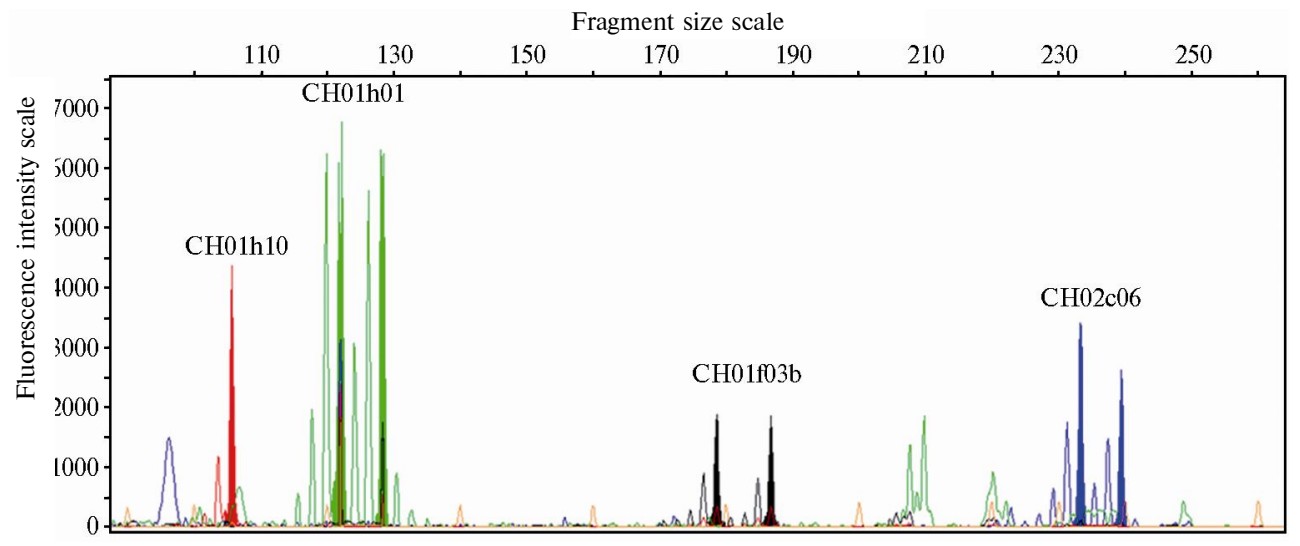

Fig. 1. Electrophoretic DNA fragment analysis for apple tree variety Krasny Yantar using a multiplex kit including SSR markers $\mathrm{CH} 01 \mathrm{~h} 10, \mathrm{CH} 01 \mathrm{~h} 01, \mathrm{CH} 01 \mathrm{f03b}$ and $\mathrm{CH} 02 \mathrm{c06}$ (collection of North Caucasian Regional Research Institute of Horticulture and Viticulture, Krasnodar) 
From the 12 markers used in the study, maximum and minimum polymorphism was revealed for locus $\mathrm{CH} 02 \mathrm{c} 11$ (10 alleles) and locus CH01f03b (5 alleles), respectively. A total of 93 alleles were detected for all 12 loci. All the varieties studied had a unique set of alleles (the obtained SSR fingerprints are given in the database which is being registered now as an item of intellectual property).

Polymorphism characteristics for the microsatellite SSR markers used in assessment of genetic diversity of modern domestic apple tree varieties (Malus $\times$ domestica Borkh.) from the collection $(n=31$, collection of North Caucasian Regional Research Institute of Horticulture and Viticulture, Krasnodar)

\begin{tabular}{|c|c|c|c|c|c|}
\hline Marker & $\begin{array}{l}\text { Range of amplified fragment sizes, } \\
\text { base pairs }\end{array}$ & $\begin{array}{l}\text { Number of iden- } \\
\text { tified alleles }\end{array}$ & PIC & $\mathrm{H}_{\mathrm{o}}$ & $\mathrm{H}_{\mathrm{e}}$ \\
\hline $\mathrm{CH} 01 \mathrm{f0} 3 \mathrm{~b}$ & $141-182$ & 5 & 0.690 & 0.710 & 0.736 \\
\hline CH01h01 & $118-137$ & 6 & 0.712 & 0.742 & 0.754 \\
\hline CH01h 10 & $94-120$ & 7 & 0.572 & 0.548 & 0.602 \\
\hline $\mathrm{CH} 02 \mathrm{c} 06$ & $204-256$ & 9 & 0.806 & 0.897 & 0.827 \\
\hline $\mathrm{CH} 02 \mathrm{~d} 08$ & $215-258$ & 9 & 0.745 & 0.800 & 0.776 \\
\hline $\mathrm{CH} 04 \mathrm{e} 05$ & $178-230$ & 9 & 0.772 & 0.867 & 0.798 \\
\hline $\mathrm{CH} 05 \mathrm{f06}$ & 171-189 & 7 & 0.678 & 0.871 & 0.723 \\
\hline $\mathrm{CH} 01 \mathrm{f0} 2$ & $173-210$ & 8 & 0.726 & 0.839 & 0.763 \\
\hline $\mathrm{CH} 02 \mathrm{cll}$ & $219-241$ & 10 & 0.727 & 0.806 & 0.752 \\
\hline $\mathrm{Hi} 02 \mathrm{c} 07$ & $104-166$ & 9 & 0.752 & 0.897 & 0.781 \\
\hline $\mathrm{CH} 02 \mathrm{c} 09$ & $235-259$ & 7 & 0.737 & 0.774 & 0.772 \\
\hline $\mathrm{CH} 03 \mathrm{~d} 07$ & $188-228$ & 7 & 0.747 & 0.679 & 0.776 \\
\hline
\end{tabular}

The comparison of the total number of the alleles identified in our study with the results of the genetic diversity analysis for the apple tree from the global gene pool allows us to state that SSR loci polymorphism is quite high in the studied sample of domestic apple tree varieties. S. Pereira-Lorenzo et al. [14] have identified a total of 122 alleles as a result of analysis of 66 Spanish apple tree varieties by $10 \mathrm{SSR}$ loci. At the same time, this figure for 27 native varieties was equal to 75 [14]. In the Finnish and Swedish apple tree gene pool (a total of 101 genotypes), 105 alleles have been identified by 9 loci. In this case, expected $\left(\mathrm{H}_{\mathrm{e}}\right)$ and observed $\left(\mathrm{H}_{\mathrm{o}}\right)$ heterozygosity values varied within $0.31-0.88$ and $0.41-$ 0.88 , respectively [23], whereas in our study they ranged within $0.548-0.897$ for $\mathrm{H}_{\mathrm{o}}$ and $0.602-0.827$ for $\mathrm{H}_{\mathrm{e}}$ (see table). The average values of $\mathrm{H}_{\mathrm{o}}$ and $\mathrm{H}_{\mathrm{e}}$ in our study were equal to 0.786 and 0.755 , respectively, which exceeded the figures obtained as a result of analysis of Scandinavian apple tree geneplasm $\left(\mathrm{H}_{\mathrm{e}}=0.72\right.$; $\left.\mathrm{H}_{\mathrm{o}}=0.74\right)$ where the average number of alleles per locus was 11.6 (23). Based on the results of our study, this parameter in a sample of 31 domestic varieties was equal to 7.75 . Studying the genetic diversity of native apple tree gene pool in north-eastern Spain (Aragon region), A. Pina et al. [24] have obtained the average value of 12.4 alleles from the analysis of 20 SSR loci in a sample of 130 genotypes. In their study, the authors compared the results with data on SSR loci polymorphism for 21 global varieties from the various regions of the world and determined that the corresponding average number of alleles per locus was equal to 8.2 [24].

The PIC values ranging from 0.572 to 0.806 (see table) indicate that most of the studied SSR markers have a high level of informativeness. In case of SSR locus CH01h10 with 7 alleles identified, the least PIC (0.572) value among the used markers was largely dependent on the prevalence of one of the alleles (with the size of 100 base pairs) over the other (it was found in $60 \%$ of the studied genotypes), as well as on the presence of two rare alleles (118 and 120 base pairs), either of which was identified only in one specimen.

Based on the SSR genotyping data, the extent of genetic similarity between the studied varieties has been assessed using the Unweighted Pair Group 
Method with Arithmetic Mean (UPGMA) (Fig. 2).

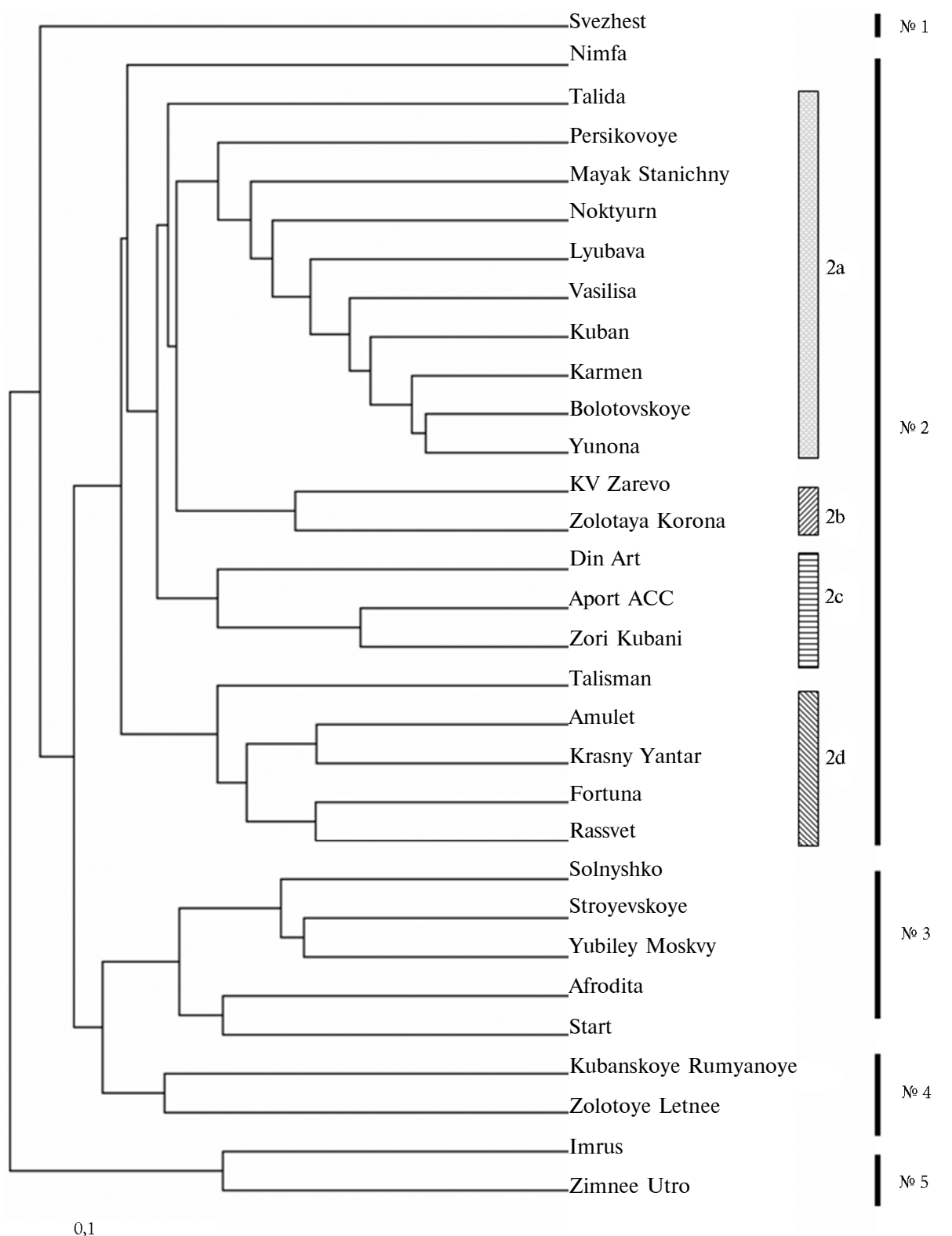

Fig. 2. The dendrogram of genetic similarity between the studied modern domestic varieties of the apple tree (Malus $\times$ domestica Borkh.), which was constructed by the UPGMA method: №№ 1-5 clusters, 2a, 2b, 2c, 2d - subclusters (collection of North Caucasian Regional Research Institute of Horticulture and Viticulture, Krasnodar).

Five main clusters have been distinguished according to the extent of genetic similarity, i.e. № 1 - variety Svezhest; № 2 - varieties Nimfa, Talida, Persikovoye, Mayak Stanichny, Noktyurn, Lyubava, Vasilisa, Kuban, Karmen, Bolotovskoye, Yunona, KV Zarevo, Zolotaya Korona, Din Art, Aport ACC, Zori Kubani, Talisman, Amulet, Krasny Yantar, Fortuna, Rassvet; № 3 - Solnyshko, Stroyevskoye, Yubiley Moskvy, Afrodita, Start; № 4 - Kubanskoye Rumyanoye, Zolotoye Letnee; № 5 - Imrus, Zimnee Utro. In this case, cluster № 2 included four subclusters (2a-2d) and varieties Talida and Nimfa. 
The results of the UPGMA analysis generally reflect genetic heterogeneity of the varieties from the studied sample. It is expressed, on the one hand, in the presence of the clusters combining several varieties at a single level or including only two (or even one in case of variety Svezhest) genotypes and, in the other hand, in formation of clusters with a complex structure (for example, № 2).

Clustering of the varieties is consistent with their origin to a large extent. For example, variety Svezhest [Antonovka Krasnobochka $\times$ PR12T67 (Uelsi $\times \mathrm{F}_{2}$ M. floribunda)] assigned to cluster № 1 and varieties Imrus (Antonovka Obyknovennaya $\times$ OR18T13) and Zimnee Utro (Liberty $\times$ Scarlet Staymared) forming cluster № 5 are originated from the varieties not represented in parent forms of any of the other varieties in the studied sample.

The reliability of the data obtained as a result of dendrogram construction is also confirmed by incorporation of varieties Afrodita, Start, Solnyshko, Yubiley Moskvy and Stroyevskoye having a common parent, the form 814 $\left[\mathrm{F}_{2}(\mathrm{M}\right.$. floribunda $821 \times M$. domestica) $] \times$ Golden Delicious [25, 26], into a single cluster, which is the most probable cause of their apartness from most of the studied genotypes based on the clustering results. Varieties Talisman, Amulet, Krasny Yantar, Fortuna and Rassvet (subcluster 2d) are originated from hybrid combination Redfri $\times$ Papirovka Tetraploidnaya.

The complex dendrite structure obtained in the course of clustering, based on the results of the SSR analysis, may be due to a large number of unique and rare alleles in the studied genotypes, which, in turn, is caused by a high genetic diversity level within the sample [27].

Thus the results of the undertaken study confirm the efficiency of SSR markers for assessment of genetic diversity of the apple tree gene pool. Based on the data obtained from analysis of SSR loci polymorphism in 31 modern domestic varieties of the apple tree, we can say that the studied sample of genotypes is characterized by a high polymorphism level. At the same time, the fact of incorporation of varieties with similar genealogy in the same clusters confirms significant genetic similarity within the groups of such varieties. In this regard we do not recommend using the varieties included into one cluster as parent pairs in hybridization if it is necessary to obtain maximum genetic variability in hybrid populations. The results of the performed SSR genotyping can be considered in confirmation of variety and hybrid genealogy if one or both of their parent forms are included in the studied sample of genotypes.

\section{REFERENCES}

1. K h a v k i n E.E. Sel'skokhozyaistvennaya Biologiya [Agricultural Biology], 1997, 5: 3-19.

2. Diw a n N., C regan P.B. Automated sizing of fluorescent-labeled simple sequence repeat (SSR) markers to assay genetic variation in soybean. Theor. Appl. Genet., 1997, 95: 723-733 (doi: $10.1007 / \mathrm{s} 001220050618$ ).

3. Thom as M.R., S cott N.S. Microsatellite repeats in grapevine reveal DNA polymorphism when analysed as sequence-tagged sites (STSs). Theor. Appl. Genet., 1993, 86: 985-990 (doi: 10.1007/BF00211051).

4. Morgante M., Oliveri A.M. PCR-amplified microsatellite markers in plant genetics. Plant J., 1993, 3: 175-182 (doi: 10.1046/j.1365-313X.1993.t01-9-00999.x).

5. Malie pa ard C., Alsto n H.F., Van Arkel G. Aligning male and female linkage maps of apple (Malus pumila Mill.) using multi-allelic markers. Theor. Appl. Genet., 1998, 97: 60-73 (doi: 10.1007/s001220050867).

6. Liebhard R., Gianffranceschi L., Koller B., Ryder C.D. Development and characterization of 140 new microsatellites in apple (Malus domestica Borkh.). Molecular Breeding, 2002, 10: 217-241 (doi: 10.1023/A:1020525906332).

7. Li ebhard R., Kolle r B., Gi anffranceschi L., Gessle r C. Creating a saturated reference map for the apple (Malus domestica Borkh.) genome. Theor. Appl. Genet., 2003, 106: 1497-1508 (doi: 10.1007/s00122-003-1209-0).

8. Silfverberg-Dilworth E. Microsatellite markers spanning the apple (Malus $\times$ domes- 
tica Borkh.) genome. Tree Genetics \& Genomes, 2006, 2: 202-224 (doi: 10.1007/s11295-0060045-1).

9. Fernandez-Fernandez F., Eans K.M., Clarke J.B., Govan C.L. Development of an STS map of an interspecific progeny of Malus. Tree Genetic \& Genomic, 2008, 4: 469479 (doi: 10.1007/s11295-007-0124-y).

10. Muzher B.M., Youn is R.A.A., E $1-\mathrm{H}$ a 1 abi O., I s mail O.M. Genetic identification of some Syrian local apple (Malus sp.) cultivars using molecular markers. Research Journal of Agriculture and Biological Sciences, 2007, 3(6): 704-713.

11. Pereira-Lorenzo S., Ramos-Cabrer A.M., Diaz-Hernandez M.B. Evaluation of genetic identity and variation of local apple cultivars (Malus domestica Borkh.) from Spain using microsatellite markers. Genet. Resour. Crop. Evol., 2007, 54: 405-420 (doi: 10.1007/s10722-006-0003-7).

12. Fua G., Simon S., Pojski c N., Kurtovic M., Peji I. Genetic assessment of apple germplasm in Bosnia and Herzegovina using microsatellite and morphologic markers. Scientia Horticulturae, 2010, 126: 164-171 (doi: 10.1016/j.scienta.2010.07.002).

13. Gharghani A., Zamani Z., Talaie A., Oraguzie N.C. Genetic identity and relationships of Iranian apples (Malus $\times$ domestica Borkh.) cultivars and landraces, wild apple species and representative old apple cultivars based on SSR markers. Genet. Resour. Crop. Evol., 2009, 56: 829-842 (doi: 10.1007/s10722-008-9404-0).

14. Pereira-Lorenzo S., Ramos-Cabrer A.M., Gonzalez-Diaz A.J., DiazHernandez M.B. Genetic assessment of local apple cultivars from La Palma, Spain, using simple sequence repeats (SSRs). Scientia Horticulturae, 2008, 117: 160-166 (doi: 10.1016/j.scienta.2008.03.033).

15. Savel'ev N.I., Yushkov A.N., Shamshin I.N. Vestnik Michurinskogo gosudarstvennogo agrarnogo universiteta, 2011, 2(1): 8-12.

16. Suprun I.I., A leks e ev Ya.I., M a ly u chenko O.P., Babakov A.V. Sadovodstvo $i$ vinogradarstvo, 2012, 4: 20-23.

17. Oraguzie N.C., Yamamoto T., Soejima J., Suzuki T. DNA fingerprinting of apple (Malus spp.) rootstocks using Simple Sequence Repeats. Plant Breed., 2005, 124: 197-202 (doi: 10.1111/j.1439-0523.2004.01064.x).

18. Patocchi A., Fernandez-Fernandez F., Evans K., Gobbin D. Development and test of 21-multiplex PCRs composed of SSRs spanning most of the apple genome. Tree Genetics \& Genomes, 2009, 5: 211-223 (doi: 10.1007/s11295-008-0176-7).

19. Richards C.M., Volk G.M., Reilley A.A., Henk A.D. Genetic diversity and population structure in Malus sieversii, a wild progenitor species of domesticated apple. Tree Genetics \& Genomes, 2009, 5: 339-347 (doi: 10.1007/s11295-008-0190-9).

20. Gross B.L., Henk A.D., Forsline P.L., Richards C.M., Volk G.M. Identification of interspecific hybrids among domesticated apple and wild relatives. Tree Genetics \& Genomes, 2012, 8(6): 1223-1235 (doi: 10.1007/s11295-012-0509-4).

21. Murray M.G., Thompson W.F. Rapid isolation of high molecular weight plant DNA. Nucl. Acids Res., 1980, 10: 4321-4325 (doi: 10.1093/nar/8.19.4321).

22. N e i M., Li W.-H. Mathematical model for studying genetic variation in terms of restriction endonucleases. PNAS USA, 1979, 76: 5269-5273 (doi: 10.1073/pnas.76.10.5269).

23. Garkava-Gustavsson L., Mujajub C., Sehic J., Zborowskaya A., Gu$\mathrm{nte} \mathrm{r}$ M.B. Genetic diversity in Swedish and Finnish heirloom apple cultivars revealed with SSR markers. Scientia Horticulturae, 2013, 162: 43-48 (doi: 10.1016/j.scienta.2013.07.040).

24. Pina A., Urrestarazu J., Pilar E. Analysis of the genetic diversity of local apple cultivars from mountainous areas from Aragon (Northeastern Spain). Scientia Horticulturae, 2014, 174: 1-9 (doi: 10.1016/j.scienta.2014.04.037).

25. S e dov E.N., $\mathrm{Z} h \mathrm{hdanov}$ V.V. Ustoichivost' yabloni $k$ parshe [Resistance to scab in apple trees]. Orel, 1983.

26. Sedov E.N., Sedysheva G.A., Zhdanov V.V., U l'y a novskaya E.V., Serov a Z.M. Vestnik VOGiS, 2009, 13(4): 793-785.

27. Urbanovich O.Yu., Kozlovskaya Z.A., Khatskevich A.A., Kartel' N.A. Izvestiya Natsional'noi akademii nauk Belarusi, 2010, 1: 12-17. 